\title{
PROSPECTIVE STUDY OF COMPOUND TIBIAL DIAPHYSEAL FRACTURES FIXED WITH UNREAMED SOLID INTRAMEDULLARY INTERLOCKING NAIL
}

\author{
Parth Gupta1, Alfven Vieira ${ }^{2}$, Ashok Ghodke ${ }^{3}$, Prateek Gohil', Saijyot Raut ${ }^{5}$ \\ ${ }^{1}$ Resident, Department of Orthopaedics, MGM Institute of Health Sciences, Navi Mumbai. \\ 2 Professor and HOD, Department of Orthopaedics, MGM Institute of Health Sciences, Navi Mumbai. \\ ${ }_{3}^{3}$ Assistant Professor, Department of Orthopaedics, MGM Institute of Health Sciences, Navi Mumbai. \\ ${ }^{4}$ Resident, Department of Orthopaedics, MGM Institute of Health Sciences, Navi Mumbai. \\ ${ }^{5}$ Resident, Department of Orthopaedics, MGM Institute of Health Sciences, Navi Mumbai.
}

\begin{tabular}{l}
\hline ABSTRACT \\
BACKGROUND \\
Rate of infection after reaming in a compound fracture was relatively high, so this study is to see results of closed solid IMIL nailing \\
without reaming.
\end{tabular}

\section{MATERIALS AND METHODS}

30 open tibial shaft fractures were treated with debridement and solid IMIL nail from June 2013 to May 2015. Gustilo Anderson classification used with 14 type 1,14 type 2, 2 type 3A. Average followup was for 6 - 9 months.

\section{RESULTS}

In one study 200 cases limited within 6 months of injury, 2 had delayed union, superficial infection $13.5 \%$ and we recommend dynamisation at 8 - 12 weeks if no evidence of infection. In our study 18 patients had excellent, 10 good and 2 had poor results.

\section{CONCLUSION}

Unreamed solid IMIL nailing is feasible in compound fractures of tibia with early mobilisation reduced rise of infection, early union and cost effectiveness.

\section{KEYWORDS}

Compound Fracture Tibia, Solid Unreamed IMIL Nail, Dynamisation.

HOW TO CITE THIS ARTICLE: Gupta P, Vieira A, Ghodke A, et al. Prospective study of compound tibial diaphyseal fractures fixed with unreamed solid intramedullary interlocking nail. J. Evolution Med. Dent. Sci. 2017;6(4):278-281, DOI: $10.14260 /$ Jemds/2017/63

\section{BACKGROUND}

The primary objective in the management of an open fracture is union with prevention or eradication of wound sepsis Gustilo et al. ${ }^{1}$ Incidence of compound fracture is increasing due to high energy trauma and are common. Tibia is a subcutaneous bone, so compound injury is more common. Management of fracture tibia requires wide experience and best clinical judgement - Watson-Jones. ${ }^{2}$ The locking of intramedullary nails to the major proximal and distal fragments decreases the prevalence of malunion of comminuted fractures. Until recently, however, all intramedullary interlocking nailing involved reaming which destroys the endosteal blood supply. ${ }^{3}$ Three goals must be met for successful treatment of open fractures of tibia, ${ }^{4}$ prevention of infection, achieve bony union and restore function. Open reduction and internal fixation in compound fractures with plate and screw have high rates of infection. ${ }^{5}$

The disadvantage of external fixation are bulky frames and non-union. ${ }^{6}$

Financial or Other, Competing Interest: None.

Submission 12-10-2016, Peer Review 01-01-2017,

Acceptance 06-01-2017, Published 12-01-2017.

Corresponding Author:

Dr. Parth Gupta,

Room No. 301,

MGM PG Hostel,

MGM Hospital,

Kamothe,

Raigad,

Navi Mumbai.

E-mail: par5569th@gmail.com

DOI: $10.14260 /$ jemds $/ 2017 / 63$
Charnley ${ }^{7}$ believed the solution for compound tibia fractures would be non-reamed intramedullary nail. Rate of infection after treatment of open tibial fractures with intramedullary nailing with reaming has been relatively high, causing most investigators to discourage the use of this technique for Grade 2 and 3 open tibial fractures. This led us to design a trial to study the results of closed solid intramedullary interlocking nailing without reaming in the treatment of open tibial shaft fractures.

\section{MATERIALS AND METHODS}

30 open fractures of tibia shaft were treated with wound debridement and undreamed solid IMIL nail from June 2013 to May 2015. All cases were fresh fractures and traumatic in nature; 30 patients who had been evaluated had followup range of $6-12$ months. There were 28 men and 2 women ranging in age from 18 to 60 years with an average of 39 years. Most of the fractures were caused by high energy trauma; 13 by a motor cycle accident and 14 from a motor vehicle and 3 from fall from height; 15 patients had associated injuries. The soft tissue injuries were classified according to system of Gustillo-Anderson classification 14 were type A1, 14 were type 2 and 2 were type $3 \mathrm{~A}$. According to AO classification of which there were 5 fractures were type A1, 5 were type A2, 6 were type A3, 8 were type B1, 6 were type B2 and none of type B3.

\section{Operative Procedure}

Patients were operated under spinal, epidural and general anaesthesia in supine position and $\mathrm{C}$-arm guidance.

Determination of nail length - length of the nail is measured from the insertion point till the level of former epiphyseal cartilage. The ruler must be aligned at the insertion point with correct reduction. 
Determination of diameter - measured at the level of isthmus. If the transition to the cortex is still visible both to the left and right of the markings, corresponding nail diameter may be used.

\section{Procedure}

Make a patellar tendon splitting incision over skin extending from inferior pole of patella till tibial tuberosity. Split the tendon. Insertion point should be slightly distal to tibial plateau, slightly medial and exactly in line with the medullary cavity. Guide wire is passed through the entry point and through the reduced fracture site under $\mathrm{C}$-arm guidance. Insert the connecting screw through the insertion handle and coupling block, then screw this assembly into the proximal end of the selected nail. Apply the insertion handle to the medial side of tibia for insertion and proximal locking. Introduce the solid IMIL nail as far as possible manually with the help of mounted instruments under C-arm guidance. Routinely proximal locking is preferred, but if there is a gap at the fracture site then distal locking is done so as to use the rebound technique to prevent diastasis at the fracture site. The proximal locking is done through the insertion handle. Skin incised, trocar inserted into the sleeve and pushed it down to the surface of bone. Remove trocar, insert drill and cortices drilled. Screw length measured by depth gauge and corresponding screw inserted with a hexagonal tip screw driver. For distal locking, the leg is placed on the table in an extended position. The C-arm is adjusted in such a way that the holes of the nail appear in a full moon position. Distal locking is done with a free hand technique. The surgical wounds are washed with betadine and normal saline. Skin sutures, sterile dressing applied and distal pulsation and capillary filling checked.

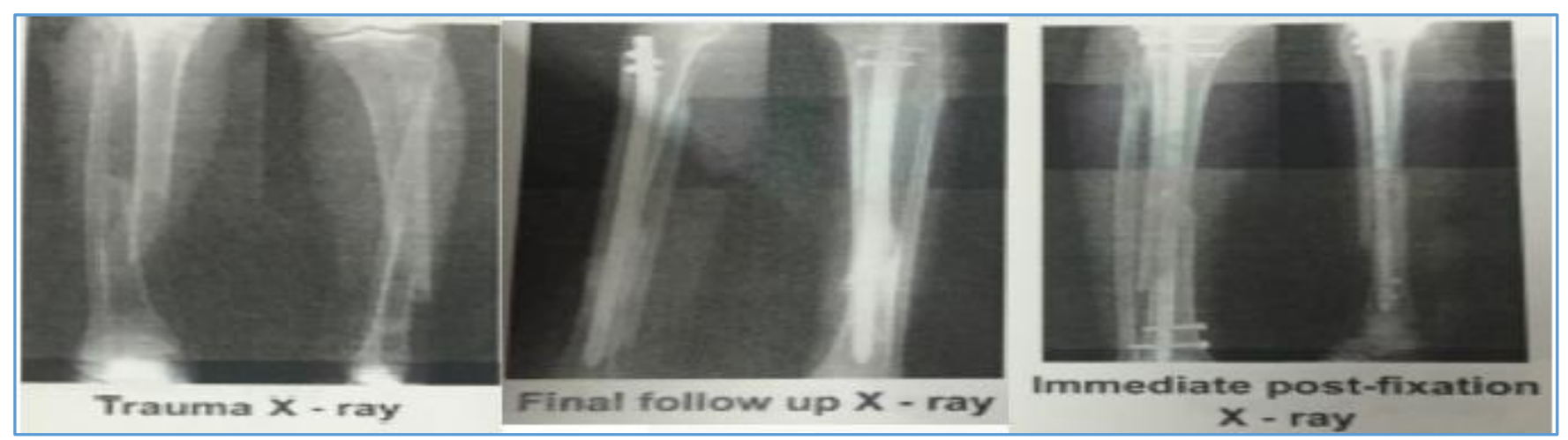

X-Ray showing Good Result of Union in Grade II Compound Tibia

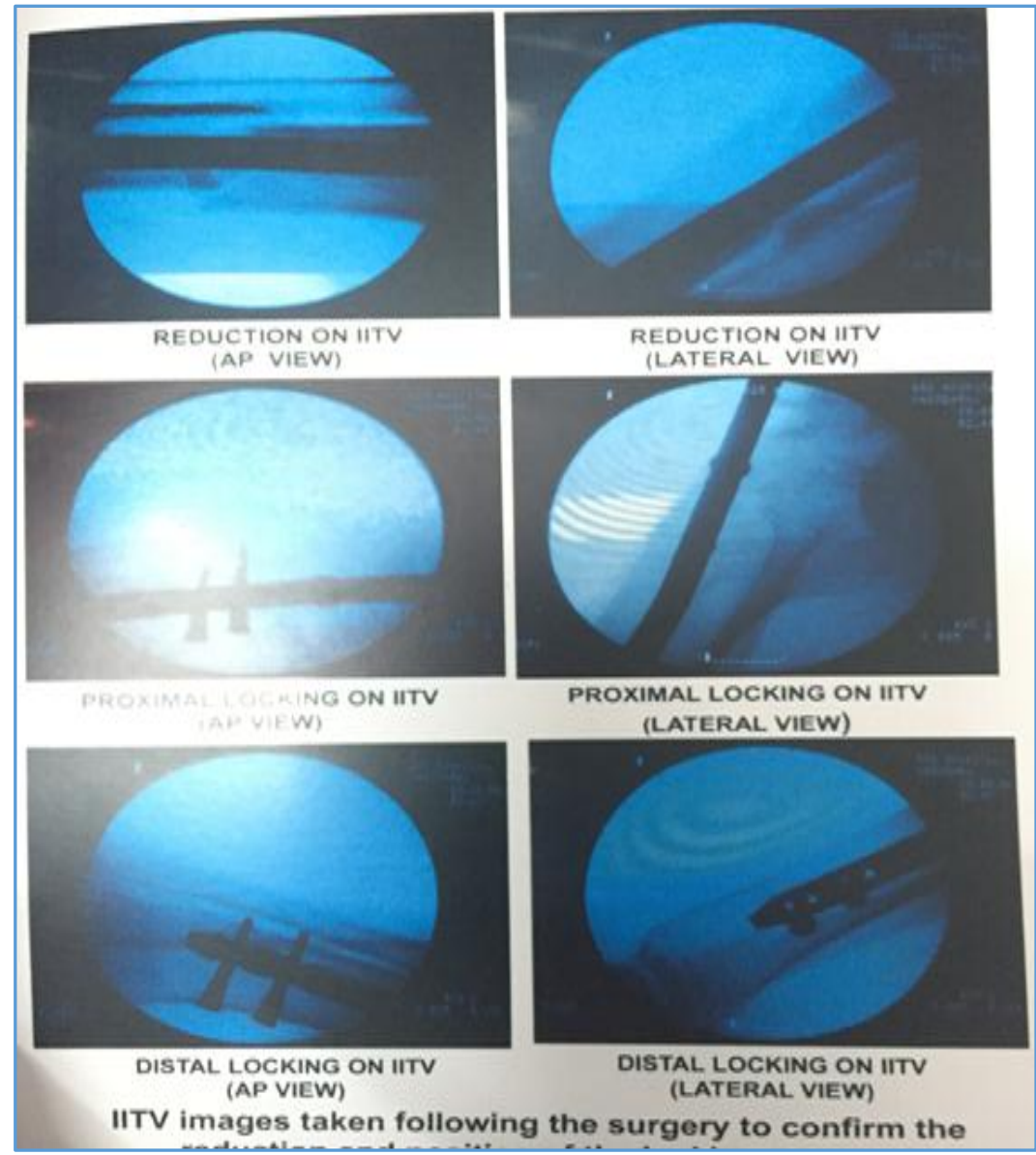




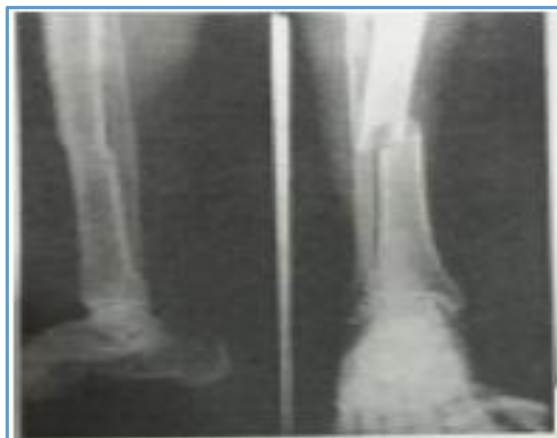

Trauma X-Ray
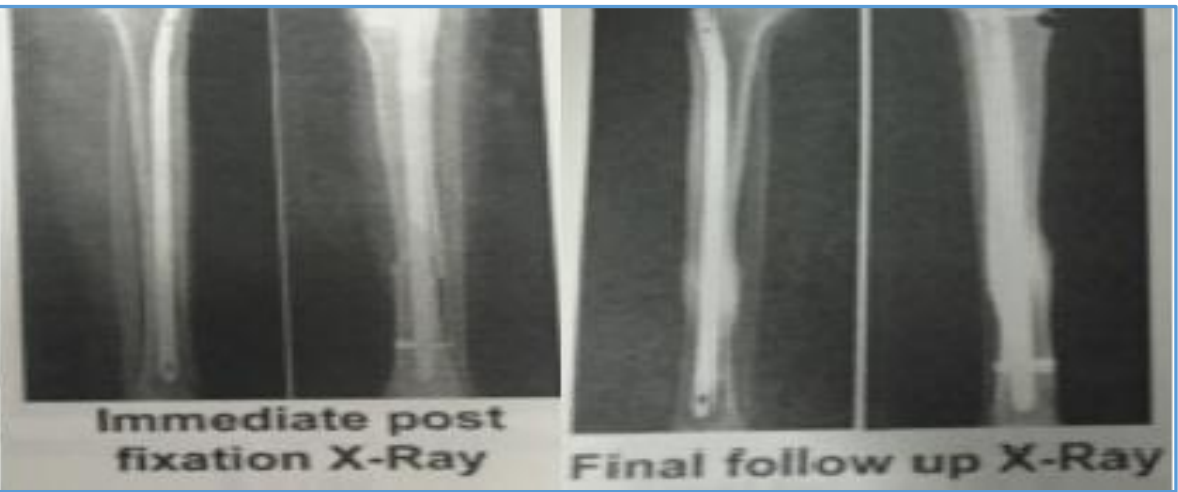

$X$-Ray showing Excellent Result

\section{RESULTS}

In our study 28 fractures united within 6 months, 4 showed superficial infection. In type 2 and 3 , the incidence of infection $13.5 \%$ compares favourably with other series showing $2.6 \%$ and $11.6 \%$. On the basis of this study, we now recommend dynamisation of most statistically locked nails at 8 - 12 weeks if callus is not evident to promote fracture union and to avoid fatigue fracture of the interlocking screws; 21 and 20 patients had full range of knee and ankle motion respectively at 14 weeks post injury. No patient developed fat embolism, compartment syndrome, peroneal nerve palsy and reflex sympathetic dystrophy.

\begin{tabular}{|c|c|c|c|}
\hline Excellent & $\begin{array}{c}\text { Functional Results } \\
\text { Gull knee and ankle motion, no } \\
\text { muscle atrophy, normal } \\
\text { radiographic alignment }\end{array}$ & 16 & 53.33 \\
\hline Fair & $\begin{array}{c}\text { Slight loss of knee and ankle } \\
\text { motion }<25^{0},<20 \text { mm muscle } \\
\text { atrophy, angular deformities }<5^{0}\end{array}$ & 11 & 36.66 \\
\hline & $\begin{array}{c}\text { Moderate loss of knee and ankle } \\
\text { motion } 25^{0}, 20 \text { mm muscle } \\
\text { atrophy, angular deformities } 5- \\
10^{0}\end{array}$ & 2 & 6.66 \\
\hline Poor & $\begin{array}{c}\text { Marked loss of knee and ankle } \\
\text { motion }>25^{0} \text { marked muscle } \\
\text { atrophy, angular deformities }>10^{0}\end{array}$ & 1 & 3.33 \\
\hline \multicolumn{4}{|c|}{ Functional Results by Klemm and Borner in 1986 } \\
\hline
\end{tabular}

\begin{tabular}{|c|c|c|}
\hline Authors & $\begin{array}{c}\text { No. of } \\
\text { Fractures }\end{array}$ & $\begin{array}{c}\text { Percentage of Union } \\
\text { within 6 Months }\end{array}$ \\
\hline Bonatus et al & 72 & 68 \\
\hline Helfet et al & 37 & 89.18 \\
\hline Saunders et al & 64 & 71.87 \\
\hline Singer and Kellam & 43 & 98 \\
\hline Stegemann et al & 41 & 95.12 \\
\hline Whittle et al & 50 & 46 \\
\hline Present Study & 30 & 93.33 \\
\hline \multicolumn{2}{|c|}{ Union Compared with Other Studies } \\
\hline
\end{tabular}

\begin{tabular}{|c|c|c|c|c|c|c|}
\hline Authors & Fractures & $\begin{array}{c}\text { Type } \\
\mathbf{1}\end{array}$ & $\begin{array}{c}\text { Type } \\
\mathbf{2}\end{array}$ & $\begin{array}{c}\text { Type } \\
\text { 3A }\end{array}$ & $\begin{array}{c}\text { Type } \\
\text { 3B }\end{array}$ & $\begin{array}{c}\text { Type } \\
\text { 3C }\end{array}$ \\
\hline Bonatus et al & 72 & 27 & 22 & 11 & 12 & 0 \\
\hline Helfet et al & 37 & 8 & 14 & 11 & 2 & 2 \\
\hline Henlety et al & 103 & 0 & 52 & 40 & 12 & 0 \\
\hline Sanders et al & 64 & 10 & 16 & 17 & 21 & 0 \\
\hline Whittle et al & 50 & 3 & 13 & 22 & 12 & 0 \\
\hline Present & 30 & 14 & 14 & 2 & 0 & 0 \\
\hline \multicolumn{7}{|c|}{ Open Tibial Fractures Treated with } \\
\hline
\end{tabular}

\section{DISCUSSION}

Recent improvement in wound coverage techniques and fixation devices have increased the prevalence of these complications, but the optimum management of open tibial shaft fractures is still evolving. 8 There are 2 major factors related to outcome of tibial shaft fractures - first, severity of fractures characterised by $\mathrm{Nicoll}^{2}$ by the degree of initial displacement, comminution and soft tissue injury. Second, damage to tibial blood supply. Brown and Urban ${ }^{9}$ reported that $27 \%$ of 63 open fractures of the tibial shaft treated with cast had healed with more than $10 \mathrm{~mm}$ shortening and $6.3 \%$ with more than $30 \mathrm{~mm}$ shortening. Smith ${ }^{5}$ studied 219 open fractures treated with internal fixation on the day of injury, delayed union occurred in $48 \%$ and infection in $20 \%$ and Reudi 10 et al reported a rate of $11 \%$ in their large series of open tibial fractures treated by plate. Bach and Hansen ${ }^{11}$ reported an incidence of infection in open tibial fractures treated with plating compared to those treated with external fixation. Johner and Wruhs ${ }^{12}$ reported non-union was twice as common and infection five times more likely when open fractures are treated with plating. Currently in Grade 1, 2 and $3 \mathrm{~A}$, open fractures the use of external fixation has been reduced due to risk of non-union and malunion. Smith ${ }^{5}$ found a rate of infection of $33 \%$ in a series of 18 open fractures treated with IMIL nail with reaming. Klemm and Borner ${ }^{13}$ reported that $6.5 \%$ developed infection after use of IMIL nail with reaming in large series of 93 Grade 1 open tibial fractures. Lottes ${ }^{14}$ reported a $7.2 \%$ rate of infection after treatment of 256 open tibial fractures with use of IMIL nail without reaming. The $27 \%$ of malunion in the series of Swanson et al demonstrates that malunion can be a problem even for fractures that have been judged to be axially stable. In current series 30 cases of compound tibial fractures were 
treated with undreamed IMIL nailing over a period of 30 months. They were followed up for an average of 10 months. The purpose of the study was to evaluate the end results of this particular modality of treatment.

\section{CONCLUSION}

Closed unreamed IMIL nailing combines the most desirable features of external fixation and of non-locking nailing without reaming. Length, alignment and rotation are controlled; the soft tissues are easily accessible and some endosteal blood supply is maintained. These factors lowers the rate of infection and malunion and expand the use of intramedullary nails to fractures near the metaphysis and with more severe comminution and soft tissue injury.

Early mobilisation, minimal hospital stay, simpler followup and overall reduced morbidity makes this modality a more preferable treatment of compound tibial fractures. In our study, 30 open tibial shaft fractures were treated with debridement and solid IMIL nail from June 2012 to May 2014. Gustilo-Anderson classification used with 14 type 1, 14 type 2 and 2 type 3A. Average followup was for 6 - 9 months. Most of the patients were operated within 8 hours of trauma as their general condition stabilised. Mean operating time was 90 minutes. Out of 30 cases 16 had excellent, 11 good, 2 fair and 1 poor results.

\section{REFERENCES}

[1] Gustilo RB. Fractures of the tibia and fibula. Chapter 47. In: Gustilo RB, Kyle RF, Templemen DC, eds. Fractures and dislocations. Mosby: Philadelphia 1992:p. 901.

[2] Jones W. Operative reduction of fractures. Chapter 16. In: Wilson JN, ed. Watson-Jones fractures and bone injuries. $6^{\text {th }}$ edn. New Delhi: Churchil Livingston 1998:p. 387.

[3] Nicoll EA. Fractures of the tibial shaft: a survey of 705 cases. JBJS 1964;46 B:373-87.
[4] Templeman DC, Gulli B, Tsukayama DT, et al. Update on the management of open tibial shaft. Clin Orthop 1998;350:18-25.

[5] Smith JE. Results of early and delayed internal fixation for tibial shaft fractures: a review of 470 fractures. JBJS 1974;56-B:469-77.

[6] Holbrook JL, Swiontkowski MF, Sanders R. Treatment of open fractures of tibial shaft. Ender nailing versus external fixation. A randomized prospective comparison. JBJS 1989;71(8):1231-8.

[7] Charnley J. Fractures of the shaft of tibia. In: The closed treatment of common fractures. Edinbrough: Churchil Livngston 1961:209-49.

[8] Whittle AP, Russell TA, Taylor JC, et al. Treatment of open fractures of tibial shaft with the use of interlocking nailing without reaming. JBJS 1992;74(8):1162-71.

[9] Brown PW, Urban JG. Early weight bearing treatment of open fractures of tibia: an end result of 63 cases. JBJS 1969;51A:59-75.

[10] Reudi T, Webb JK, Allgower M. Experience with the dynamic compression plate in 418 recent fractures of tibial shaft. Injury 1976;7:252-7.

[11] Hansen ST. Overview of the severely traumatized lower limb. Reconstruction versus amputation. Clin Orthop Relat Res 1989;243:17-9.

[12] Johner R, Wruhs O. Classification of tibial shaft fractures and correlation with results after rigid internal fixation. Clin Orthop Relat Res 1983;178:7-25.

[13] Klemm KW, Borner M. Interlocking nailing of complex fractures of tibia and femur. Clin Orthop Relat Res 1986;212:89-100.

[14] Lotttes JO. Medullary nailing of tibia with triflange nail. Clin Orthop Relat Res 1974;105:53-66. 